\title{
SANKSI ADMINISTRATIF PELANGGARAN ANALISIS DAMPAK LALU LINTAS
}

\section{Oleh :}

\author{
Abdul Basid*, Triyo Amianto** \\ * Fakultas Hukum, Universitas Gresik \\ Email : abdulbasid654@gmail.com \\ ** Fakultas Hukum, Universitas Gresik \\ Email : triyoamianto45@gmail.com
}

\begin{abstract}
ABSTRAK
Seiring meningkatnya kemampuan ekonomi dan kesejahteraan masyarakat, meningkat pula pertumbuhan konsumsi terhadap barang dan jasa publik. Kondisi ini ditandai atas melonjaknya berbagai pusat kegiatan, industri, infrasruktur, maupun kawasan pemukiman di berbagai kota di Indonesia. Diantaranya akses negatif melonjaknya perkembangan ekonomi rakyat adalah bertambahnya besarankepemilikan kendaraan yang berakibatterhadap kepadatan lalu lintas. Terjadi kemacetan dimana-mana dengan ekses beban ekonomi tinggi, berkembangnya resiko akan keamanan, keselamatan, ketertiban, dan kelancaran aktifitas di jalan. Perkembangannya bisasebagai kontra produktif atassasaran pembentukan ekonomi dan perluasan wilayah, dikarena kemacetan mempengaruhimasa perjalanan. Kendaraan yang beroperasiselama kemacetan, mengakibatkan beban ekonomi tinggi dampak konsumsi bahan bakar yang semakin banyak.

Kota menggambarkansuatu wilayah yang memiliki penduduk relatif banyak. Besaran penduduk di kota-kota besar khususnya Kota Gresik terus bertambah, faktor penyebab jumlah penduduk terus bertambah di Kota Gresik dikarenakan urbanisasi desa/kota-kota kecil ke Kota Gresik atas tujuan mencari pekerjaan. Besarnya urbanisasi desa/kotakecil ke Gresik mengakibatkan banyaknyaharapan penduduk akan mencukupi kebutuhan hidupnya. Mall adalah pusat perbelanjaan yang mempromosikan berbagai aneka ragam barang yang dijual sehingga konsumen beramai-ramai datang kesana. Banyaknya pembangunan mall di Kota Gresik kadangkadang tidak disertai atas ijin analisis dampak lalu lintas (andalalin). Sedangkanandalalin benar-benar penting dilaksanakan ketika mall tersebut dibangun supaya tidak berlangsung kemacetan yang diakibatkankarena kendaraan yang masuk/keluar mall tersebut.

Persoalan perizinan toko modern terus berlanjut. Dinas Perhubungan (Dishub) memaparkan jika seluruh toko modern yang ada di Kabupaten Gresik tidak memiliki analisis dampak lalu lintas. Ini disebabkan karena Gresik baru mengatur andalalin atas tahun 2017 lalu. Yakni dengan terbitnya Perda 4/2017 tentang Analisis Dampak Lalu Lintas.

Pemberian sanksi yang akan diberikan yakni penderitaan yang diberikan ataupunkelihatan dengan sengaja oleh seseorang sesudah terjadi suatu pelanggaran, kejahatan dan kesalahan yang dilakukan karena seseorang sebagai salah satu cara pendisiplinan.
\end{abstract}

Kata kunci: Analisis Dampak Lalu Lintas; Pelanggaran;Perizinan; Sanksi. 


\begin{abstract}
As economic capacity and social welfare increase, so will the growth in consumption of public goods and services. This condition is marked by the surge in various activity centers, industries, infrastructure, and residential areas in various cities in Indonesia. Among them is the negative access to the soaring economic development of the people, namely the increase in the amount of vehicle ownership which results in traffic congestion. Traffic jams occur everywhere with high excess economic burdens, developing risks of security, safety, order and smooth activity on the road. Its development can be counterproductive to the goals of economic formation and regional expansion, because congestion affects travel times. Vehicles that operate during congestion, resulting in a high economic burden due to increased fuel consumption.

City describes an area that has a relatively large population. The population size in big cities, especially Gresik City continues to increase, the factor that causes the population to continue to increase in Gresik City is due to the urbanization of villages / small towns to Gresik City for the purpose of finding work. The large number of urbanization in the village / small town to Gresik has resulted in many hopes that the population will fulfill their daily needs. Mall is a shopping center that promotes a wide variety of goods sold so that consumers flock to there. The large number of mall developments in Gresik City is sometimes not accompanied by a traffic impact analysis permit (andalalin). Meanwhile, andalalin is really important to implement when the mall is built so that congestion does not occur due to vehicles entering / leaving the mall.

The issue of licensing for modern shops continues. The Department of Transportation (Dishub) explained that all modern shops in Gresik Regency do not have a traffic impact analysis. This is because Gresik has only managed Andalalin in 2017. Namely with the issuance of Perda 4/2017 on Traffic Impact Analysis.

The imposition of sanctions that will be given, namely the suffering that is given or seen on purpose by someone after an offense, crime and wrongdoing is done because of someone as a way of disciplining.
\end{abstract}

Keywords: Traffic Impact Analysis; Violation; Licensing; Penalty. 
A. Pendahuluan

\section{A. Latar Belakang}

Melonjaknya

kemacetan

terhadap jalanan perkotaan maupun jalanan luar kota dikarenakan meningkatnya kepunyaan akan transportasi, terbatasnya sumberdaya akan pembentukan jalan, dan belum optimalnya pendayagunaan layanan lalu lintas yang ada, adalah permasalahan penting diberbagai negara.

Seiring

kemampuan

meningkatnya ekonomi dan kesejahteraan masyarakat, meningkat pula pertumbuhan konsumsi terhadap barang dan jasa publik. Kondisi ini ditandai atas melonjaknya berbagai pusat kegiatan, industri, infrasruktur, maupun kawasan pemukiman di berbagai kota di Indonesia. Diantaranya akses negatif melonjaknya perkembangan ekonomi rakyat adalah bertambahnya besaran kepemilikan kendaraan yang berakibat terhadap kepadatan lalu lintas. Terjadi kemacetan dimana-mana dengan ekses beban ekonomi tinggi, berkembangnya resiko akan keamanan, keselamatan, ketertiban, dan kelancaran aktifitas di jalan. Perkembangannya bisasebagai kontra produktif atas sasaran pembentukan ekonomi dan perluasan wilayah, dikarena kemacetan mempengaruhi masa perjalanan. Kendaraan yang beroperasi selama kemacetan, mengakibatkan beban ekonomi tinggi dampak konsumsi bahan bakar yang semakin banyak.

Dampak kemacetan tidak cuma dinikmati untuk masyarakat di jalan raya, akan tetapi pengguna jalan lainnya. Polusi, baik polusi udara ataupun suara turut berkontribusi di dalamnya. Dapat difikirkan apa yang akan terjadi bila ini terus berlanjut, penyakit dipernafasan, kanker atau kelainan dampak pencemaran logam dapat terjadi karena kendaraan yang dinyalakan saat kondisi tidak bergerak (macet) mengeluarkan lebih banyak gas beracun akibat pembakaran tidak sempurna yang memberi dampak akumulasi gas beracun yang diproduksikan. Kemacetan secara tidak langsung dapat pula memicu penyakit pernafasan akut, menurunkan fungsi otak atau bahkan kematian.

Transportasi menggambarkan kebutuhan turunan (derived demand) dampak adanya kegiatan ekonomi, sosial budaya dan lain-lain. Didalam konteks makro ekonomi, transportasi menggambarkan tulang punggung perekonomian di tingkat nasional, regional ataupun lokal, untuk wilayah perkotaan maupun pedesaan. Kota Gresik akan potensi yang lumayan besar baik dibagian pariwisata ataupun industri membuahkan nilai lebih untuk peluang bisnis dan investasi. Dengan demikian kegiatan yang berjalan akibat terbangunnya pusat kegiatan /penataan lahan sebagaimana, adanya Pemukiman, Rumah Sakit, Sekolah, Pasar, Butik, dan Pertokoan yang bisa mengakibatkan perubahan yang besar dan akibatnya dapat mempengaruhi volume lalu lintas.

Kota menggambarkan suatu wilayah yang memiliki penduduk relatif banyak. Besaran penduduk di kota-kota besar khususnya Kota Gresik terus bertambah, faktor penyebab jumlah penduduk terus bertambah di Kota Gresik dikarenakan urbanisasi desa/kota-kota kecil ke Kota Gresik atas tujuan mencari pekerjaan. Besarnya urbanisasi desa/kota kecil ke Gresik mengakibatkan banyaknya harapan penduduk akan mencukupi kebutuhan hidupnya. Mall adalah pusat perbelanjaan yang mempromosikan 
berbagai aneka ragam barang yang dijual sehingga konsumen beramairamai datang kesana. Banyaknya pembangunan mall di Kota Gresik kadang-kadang tidak disertai atas ijin analisis dampak lalu lintas (andalalin). Sedangkan andalalin benar-benar penting dilaksanakan ketika mall tersebut dibangun supaya tidak berlangsung kemacetan yang diakibatkan karena kendaraan yang masuk/keluar mall tersebut.

Persoalan perizinan toko modern terus berlanjut. Dinas Perhubungan (Dishub) memaparkan jika seluruh toko modern yang ada di Kabupaten Gresik tidak memiliki analisis dampak lalu lintas (andal lalin). Ini disebabkan karena Gresik baru mengatur andalalin atas tahun 2017 lalu. Yakni dengan terbitnya Perda 4/2017 tentang Analisis Dampak Lalu Lintas.

Kabupaten Gresik selaku diantara kota besar Provinsi Jawa Timur adalah wilayah dengan mobilitas tinggi, aktivitas warga yang sangat beragam dan besaran penduduk yang amat tinggi. Alat transportasi yang cukup mutlak diperlukan untuk menjunjung kegiatan dari masyarakat. Makin tingginya besaran penduduk sehingga kebutuhan atasalat transportasi semakin berkembang.

Lalu lintas menggambarkan masalah serius sebab lalu lintas merupakan alat untuk berjalan dari satu tempat ke tempat lainya. Jika lalu lintas terganjal atau terjadi kemacetan, maka mobilitas masyarakat dapat mengalami gangguan. Gangguan tersebut bias berakibatkan pemborosan bahan bakar, pemborosan masa waktu dan bisa menyebabkan polusi udara.

Permasalahan lalu lintas menggambarkan masalah yang amat serius, dikarenakan masalah tersebut merupakan masalah berat yang wajib dipecahkan bersama-sama. Bilamana masalah lalu lintas belum terpecahkan, Kemungkinan masyarakat sendiri yang akan mengalami kerugian, dan bilamana masalah ini bisa terpecahkan dengan benar, maka masyarakat sendiri yang memperoleh manfaatnya.

Pengaruh lalu lintas disebabkan adanya atas pembangunan dan pelaksanaan pusat aktivitas yang mengakibatkan bangkitan lalu-lintas yang lumayan banyak, seperti pusat perkantoran pusat perbelanjaan, terminal, dan lain-lain.

Dengan adanya penjelasan diatas, maka dapat ditemukan beberapa persoalan tentang penerapan Peraturan Daerah Kabupaten Gresik dengan kondisi dilapangan yang banyak ditemukan pelanggarpelanggar lalu lintas yang setiap hari ada.

Dalam latar belakang tersebut maka penulis bisa mendapatkan ide untuk membuat skripsi dengan judul "SANKSI

\section{ADMINISTRATIFPELANGGARAN}

\section{ANALISIS DAMPAK LALU LINTAS "}

\section{B. Rumusan Masalah}

Berdasarkan uraian latar belakang permasalahan di atas, maka rumusan masalah dalam penelitian ini adalah:

a. Bagaimanakah pengertian pengembang atau pembangun dalam pasal 20 Peraturan Daerah Kabupaten Gresik Nomor 04 Tahun 2017?

b. Bagaimanakah pemberian sanksi administratif terhadap pemegang izin analisis dampak lalu lintas (Andalalin) yang sudah dialihkan hak nya?

\section{Tujuan Penelitian}

Penelitian ini bertujuan untuk mengidentifikasi dan mengkaji 
bagaimana masalah tentang pengertian Peraturan Daerah Kabupaten Gresik No. 4 Tahun 2017 dan pemberian sanksi administratif bagi pelanggar Peraturan Daerah Kabupaten Gresik No. 4 Tahun 2017. Tujuan tersebut di atas dirinci lebih lanjut sebagai berikut:

a. Mengetahui dan memahami aturan yang berlaku pada Peraturan Daerah Kabupaten Gresik Nomor 04 Tahun 2017 tentang Analisis Dampak Lalu Lintas.

b. Mengetahui dan memahami bagaimana proses pemberian sanksi terhadap pelanggar terkait dengan Peraturan Daerah Kabupaten Gresik Nomor 04 Tahun 2017 Tentang Analisis Dampak Lalu Lintas.

\section{Manfaat Penelitian}

Penelitian ini diharapkan memberi manfaat :

1. Secara Teoritis, hasil penelitian ini diharapkan dapat menjadi bahan untuk dikembangkan lebih lanjut terkait hukum - hukum yang tercantum dalam Peraturan Daerah Kabupaten Gresik Nomor 04 Tahun 2017 Tentang Analisis Dampak Lalu Lintas.

2. Secara Praktis, hasil penelitian ini diharapkan dapat memberi masukan kepada Pemerintah Kabuapten Gresik dan Pengembang Proyek agar lebih transparansi dalam publikasi perijinan pembangunan infrastruktur..

\section{E. Metode Penelitian}

\section{A. Jenis Penelitian}

Penelitianhukum empiris (socio legal research atau non doktriner) yaitu mengkaji pelaksanaan atau implementasi ketentuan hukum positif (perundang-undangan) dan kontrak secara factual pada setiap peristiwa hukum tertentu yang terjadi dalam masyarakat guna mencapai tujuan yang telah ditentukan. Pengkajian tersebut bertujuan untuk memastikan apakah hasil penerapan pada peristiwa hukum inconcreto itu sesuai atau tidak sesuai dengan ketentuan undangundang. Dengan kata lain apakah ketentuan undang-undang telah dilaksanakan sebagaimana patut atau tidak, sehingga pihak-pihak yang berkepentingan mencapai tujuan atau tidak.

Penelitian hukum normative empiris (terapan) bermula dari ketentuan hukum positif tertulis (perundang-undangan) yang diperlakukan pada peristiwa hukum in concreto dalam masyarakat. Pada penelitian ini mengkaji sebuah subjek penelitian akibat hukum dan perijinan pada Peraturan Daerah Kabupaten Gresik Nomor 4 Tahun 2017 Tentang Analisis Dampak Lalu Lintas.

\section{B. Sumber Bahan Hukum}

Penelitian ini membutuhkan 2 (dua) jenis data. Data yang akan dikumpulkan adalah data primer dan data sekunder.

a. Data Primer adalah data yang diperoleh secara langsung pada obyek yang diteliti atau obyekobyek penelitian yang ada hubungannya dengan pokok masalah. Data primer ini diperoleh dengan cara wawancara secara langsung dengan responden dan pengamatan terhadap obyek yang diteliti yaitu Badan Penanaman Modal dan Perizinan , Dinas Perhubungan Kabupaten Gresik.

b. Bahan hukum sekunder, yaitu bahan hukum yang erat hubungannya dengan bahan hukum primer dan dapat membantu menganalisis serta memahami bahan hukum primer tersebut berupa naskah-naskah,hasil penelitian terkait, makalah, buku- 
buku karya dari para pakar hukum, jurnal hukum, surat kabar serta bahan tulisan lain yang ada kaitannya dengan masalah yang diteliti.

c. Bahan hukum primer, yaitu bahan hukum yang mengikat yang terdiri dari:

1. Undang-undang Nomor 22 Tahun 2009 tentang Lalu Lintas dan Angkutan Jalan.

2. Undang-undang No. 28 Tahun 2002 tentang Bangunan Gedung.

3. Peraturan Daerah No. 06 Tahun 2017 tentang Izin Mendirikan Bangunan.

4. Peraturan Daerah Kabupaten Gresik Nomor 04 Tahun 2017 tentang Analisis Dampak Lalu Lintas

\section{F. PEMBAHASAN}

\section{A. Pengertian Subjek Hukum}

Indonesia yakni negara hukum yang mengakui setiap orang sebagai manusia terhadap undang-undang yang artinya bahwa setiap orang diakui sebagai subyek hukum.

Berdasarkan pendapat para sarjana di atas dapat disimpulkan bahwasannya subyek hukum adalah segala sesuatu yang dapat memperoleh hak dan kewajiban dari hukum sehingga segala sesuatu yang dimaksud dalam pengertian tersebut adalah manusia dan badan hukum. Jadi, manusia oleh hukum diakui sebagai penyandang hak dan kewajiban sebagai subyek hukum atau sebagai orang. ${ }^{1}$

${ }^{1}$ Rachmadi Usman, “Aspek-Aspek Hukum Perorangan dan Kekeluargaan di Indonesia", Sinar Grafika, Jakarta, 2006, h. 72.
Subyek hukum mempunyai kedudukan dan peranan yang sangat penting dalam hukum, khususnya hukum keperdataan karena subyek hukum tersebut yang dapat mempunyai wewenang hukum. Dalam lapangan hukum perdata mengenal subyek hukum sebagai salah satu bagian dari kategori hukum yang merupakan hal yang tidak dapat diabaikan karena subyek hukum adalah konsep dan pengertian (concept en begriff) yang mendasar. ${ }^{2}$

Manusia yakni subyek hukum yang memiliki hak dan sanggup menjalankan haknya dijamin bagi hukum yang resmi. Manusia yakni subyek hukum itu diatur secara luas pada Buku 1 KUH Perdata tentang orang (van personen), UndangUndang kewarganegaraan, dan UU orang asing.

\section{B. Pengertian Penerapan Sanksi}

Seorang

filosof

Yunani,Aristoteles, mengatakan bahwa manusia adalah zoon politicon, artinya manusia merupakan makhluk yang hidup bermasyarakat. Sejak lahir hingga meninggal, manusia hidup ditengah-tengah masyarakat dan melakukan hubungan dengan manusia yang lain. Hubungan antara seseorang dengan orang-orang lain mungkin bersifat langsung ataupun tidak langsung. Hubungan itu menyebabkan kehidupan bermasyarakat antara manusia saling membutuhkan satu dengan yang lainnya. Kebutuhan dapat sama dengan satu yang lainnya, atau

\footnotetext{
${ }^{2}$ Rosnidar Sembiring, "Hukum Keluarga (Harta-Harta Benda Dalam Perkawinan)",Raja Grafindo Persada, Jakarta, 2016, h.7.
} 
bahkan dapat bertentangan/ berlawanan. $^{3}$

Bertentangan yakni dapat memicu perselisihan dan kekacauan didalam masyarakat, agar membereskan diadakan ketentuan yang mengatur yaitu tata tertib yang dapat mengembangkan kepentingan yang bertentangan tersebut, sehingga timbul kedamaian. Ketentuan ketentuan tersebut merupakan petunjuk hidup yang merupakan hukum yang berkembang bersamasama masyarakat atau dengan lain perkataan hukum berarti tertib social.

\section{Sanksi Administratif}

Atas hakikatnya hukum administrasi negara mengharuskan pelaku administrasi negara agar melaksanakan kegunaannya dan melindungi masyarakat atas sikap administrasi negara, serta melindungi administrasi negara itu sendiri. Tugas pemerintah yang menjalankan karena perlengkapan negara ataupun administrasi negara harus diberi landasan hukum yang mengatur dan melandasi administrasi negara dalam melaksanakan fungsinya. Hukum yang memberikan landasan tersebut dinamakan hukum administrasi negara.

Perbedaan antara sanksi administrasi dan sanksi pidana dapat dilihat dari tujuan pengenaan sanksi itu sendiri. Sanksi administrasi ditujukan kepada perbuatan pelanggarannya, sedangkan sanksi pidana ditujukan kepada si pelanggar dengan memberi hukuman berupa nestapa. Sanksi administrasi

\section{R. Soeroso, "Pengantar Ilmu} Hukum", Cet.VIII, Sinar Grafika, Jakarta, 2006, h. 40. dimaksudkan agar perbuatan pelanggaran itu dihentikan. Sifat sanksi adalah reparatoir artinya memulihkan pada keadaan semula. Di samping itu perbedaan antara sanksi pidana dan sanksi administrasi ialah tindakan penegakan hukumnya. Sanksi adminitrasi diterapkan oleh pejabat tata usaha negara tanpa harus melalui prosedur peradilan, sedangkan sanksi pidana hanya dapat dijatuhkan oleh hakim pidana melalui proses pengadilan. ${ }^{4}$

\section{Pengertian Sanksi Dan} Pemberian Sanksi

Sanksi adalah kesengsaraan yang diberikan ataupun kelihatan dengan sengaja karena seseorang setelah terjadi suatu pelanggaran, kejahatan dan kesalahan.Menurut Kamus Besar Bahasa Indonesia sanksi adalah tindakan tindakan hukuman untuk memaksa seseorang menaati aturan atau menaati undang-undang. Sanksi (punnishment) merupakan pemberian hasil yang tidak diinginkan (menyakitkan) untuk meminimalisir perilaku yang tidak diinginkan. Sanksi merupakan salah satu indikator yang memperbaiki jalannya proses pendidikan dalam menjelaskan perilaku seseorang, sehingga pada waktu yang mau datang dapat diatasi.

Pemberian sanksi adalah memberikan penderitaan yang diberikan ataupun kelihatan dengan sengaja oleh seseorang sesudah terjadi suatu pelanggaran, kejahatan dan kesalahan yang dilakukan karena

4 Philipus M. Hadjon, "Pengantar Hukum Administrasi Indonesia", Cet.X., Gadjah Mada University Press, Yogyakarta, 2008, h. 247. 
seseorang sebagai salah satu cara pendisiplinan.

Penjelasan diatas dapat disimpulkan bahwa pemberian sanksi adalah suatu proses dimana untuk memberikan efek kepada seseorang yang telah melakukan pelanggaran.

\section{G. PENUTUP}

\section{A. Kesimpulan}

a. Secara umum Peraturan Daerah Gresik Nomor 4 Tahun 2017 tentang Analisis Dampak Lalu Lintas belum sepenuhnya berjalan baik. Hal ini dapat dilihat dari permasalahanpermasalahan yang masih muncul dalam pelaksanaan Perda tersebut.

b. Dari aspek pelayanan yang belum sinergi antara Dinas Perhubungan, Dinas Satuan Polisi Pamong Praja, Karena sebagai penggerak kebijakan yang berada dilapangan seharusnya memiliki sinergi agar pelanggar dapat diminimalisir maupun dapat mengurangi resiko dan bahaya di Kabupaten Gresik.

\section{B. Saran}

Sebagai bentuk kepedulian peneliti terhadap persoalan yang ada, maka peneliti mengajukan beberapa saran dan rekomendasi sebagai berikut

a. Bagi Pemerintah :

a. Pemerinatah Kabupaten Gresik harus berkomitmen dalam peningkatan pelayanan lalu lintas dan pengendalian tata ruang Kabupaten Gresik dalam bentuk kebijakan. Kepala Dinas Perhubungan dan Satpol PP sebaiknya membagi pasukan nya di zona - zona rawan maupun area pengerjaan bangunan. b. Dinas Satuan Polisi Pamong Praja hendaknya meningkatkan pengawasan di tempat - tempat yang berpotensial akan pembangunan. Jika lingkungan rusak maka akan berdampak buruk bagi Kabupaten Gresik seperti terjadinya kemacetan maupun korban jiwa yang merugikan. Pembiaran bangunan yang melanggar akan menjadi masalah besar di kemudian hari.

b. Bagi Masyarakat:

Masyarakat hendaknya berperan aktif dalam implementasi sebuah kebijakan karena kebijakan tersebut ditujukan bagi kehidupan bersama yang lebih baik dan masyarakat memiliki peranan penting dalam memberikan masukan terhadap pelaksanaan kebijakan

c. Bagi Peneliti Selanjutnya :

Bagi peneliti selanjutnya dapat dilakukan penelitian mengenai lokasi strategis Pada saat penelitian, peneliti menemukan data bahwa banyak areaarea maupun lokasi rawan bahaya maupun kemacetan di Kabupaten Gresik. Sehingga diperlukan kajian tentang hal tersebut mengingat lahan di Kabupaten Gresik terbatas. dan kurang lemahnya petugas maupun pengawasan melalui jarak jauh.

\section{H.DAFTAR BACAAN}

\section{Buku-buku}

M. Hadjon, Philipus, "Pengantar Hukum Administrasi Indonesia", Cet.X., Gadjah Mada University Press, Yogyakarta, 2008.

$\begin{array}{cr}\text { Sembiring, } & \text { Rosnidar,"Hukum } \\ \text { Keluarga } & \text { (Harta-Harta Benda } \\ \text { Dalam } & \text { Perkawinan)",Raja } \\ \text { Grafindo Persada, Jakarta, 2016. }\end{array}$


Soeroso, R., "Pengantar Ilmu

Hukum", Cet.VIII, Sinar

Grafika, Jakarta, 2006.

Usman, Rachmadi Usman, "AspekAspek Hukum Perorangan dan Kekeluargaan di Indonesia", Sinar Grafika, Jakarta, 2006. 